\title{
Ethnomedicinal Uses of tawatawa (Euphorbia hirta Linn.) in Selected Communities in the Philippines: a Non-invasive Ethnographic Survey Using Pictures for Plant Identification
}

\author{
Hilton Y. Lam, ${ }^{1,2}$ Marco Nemesio E. Montaño, ${ }^{3}$ Isidro C. Sia, ${ }^{4}$ Francisco M. Heralde III ${ }^{5}$ and Lotgarda Tayao ${ }^{1}$ \\ ${ }^{1}$ Institute of Health Policy and Development Studies, National Institutes of Health, University of the Philippines Manila \\ ${ }^{2}$ Institute of Clinical Epidemiology, National Institutes of Health, University of the Philippines Manila \\ ${ }^{3}$ Marine Science Institute, College of Science, University of the Philippines Diliman \\ ${ }^{4}$ Department of Pharmacology and Toxicology, College of Medicine, University of the Philippines Manila \\ ${ }^{5}$ Department of Biochemistry and Molecular Biology, College of Medicine, University of the Philippines Manila
}

\begin{abstract}
Background. There is a growing interest in the use of Euphorbia hirta Linn. as herbal remedy for dengue, supposedly based on folkloric practice. However, there has been no ethnobotanical documentation of such use in the Philippines. Because of this, the medical community cautions the public against the sole use of $E$. hirta in treating dengue.
\end{abstract}

General Objective. To describe the ethnomedicinal uses of Euphorbia hirta Linn. In selected communities in the Philippines.

Specific Objectives. (1) To identify the vernacular names of the plant; (2) to identify the earliest known use of the plant against dengue infection and for other indications; (3) to document the methods of preparation and administration, side effects, and contraindications of use.

Methods. Cross-sectional descriptive design using the snowball sampling of interviewer-guided key informants for the ethnobotanical interview.

Limitations. The results of this study may be limited by its convenient sampling design and the use of plant pictures with different magnifications.

Results and Conclusion. Majority of the respondents were female (93\%), 41-60 years old (39\%), had high school education (43\%), and resided in Quezon City (31\%). The plant is locally known as tawatawa, butobutonesan, malagatas, and mangagaw. It has been used to treat fever in the Philippines as early as 1948. Its use as a treatment for dengue started only in the 1980s. The plant is either squeezed, crushed, or boiled, and is administered topically or orally. The only reported side-effect is increased urinary frequency.

Recommendations. It is recommended that more comprehensive and large scale studies be conducted, including: (1) identification of folkloric uses of E. hirta for the treatment of other diseases; (2) determination of different concentrations of extract (crude or semicrude) using the various reported preparations for optimal outcomes for the different reported medicinal uses.

Key Words: Euphorbia hirta, ethnomedicine, Philippines, tawatawa

Corresponding author: Hilton Y. Lam, MHA, PhD Institute of Health Policy and Development Studies National Institutes of Health

University of the Philippines Manila

E-mail: hiltonyulam@gmail.com 


\section{INTRODUCTION}

Euphorbia birta is a small meso-xerophytic annual herb that belongs to the family Euphorbiaceae, also known as the Spurge family, which is the sixth largest family of flowering plants, accounting for almost one sixth of all known flowering plants, and consisting of approximately 8,900 genera. ${ }^{1}$ It has a hairy stem that is much-branched from the base. These ascending branches may be simple or forked, slender, with a reddish or purplish color, where broad leaves emanate. It grows up to 30-40 centimeters in height. Its short and oblong shaped leaves grow in opposition to each other. The edges of the leaves are serrated and they usually exhibit a purple mark in the center. The plant displays purple flowers which are small and clustered. The inflorescence is cyathophorous and the flower is unisexual. ${ }^{2}$ The cyathium is clustered in dense, crowded cymes wherein the involucres are stalked, and cup-shaped. Each involucre contains one female flower surrounded by many male flowers, with no perianth. The plant has milky latex in all its parts. ${ }^{1}$ It thrives in open wastelands, grasslands, pathways, and roadsides.

Currently, in the Philippines, there is a growing interest in E. hirta, particularly its claimed effect on increasing the platelet count of dengue patients. ${ }^{3,45}$ Because this has not yet been scientifically proven, the medical community is cautioning the public against the sole use of E. hirta in treating dengue. ${ }^{6,7,8}$ The general objective of this study was to document the traditional medicinal uses of E. hirta in selected communities across the country.

The Philippine Department of Health, through the Philippine Food and Drug Administrative Order No. 184, s. 2004, "Guidelines on the Registration of TraditionallyUsed Herbal Products", which specifies that local plant materials can be licensed for use as medicine as long as there is documented "traditional experience of long usage which should be at least five (5) or more decades as documented in medical, historical and ethnological literature," provided there is an "absence of unsuspected potential for systematic toxicity, carcinogenicity, and teratogenicity," and there is "no valid report of adverse drug reaction on the use of the plant material as determined by the BFAD", "no valid report of abuse or dependence," and "contains no chemically defined therapeutically active substances." Specifically, this study (1) identified the vernacular names of the plant; (2) documented the reported earliest known use of the plant against dengue infection; and (3) recorded the methods of preparation and administration, side effects, and contraindications of use.

\section{REVIEW OF LITERATURE}

E. hirta has been reported in several parts of the world as a herbal remedy for febrile illnesses particularly dengue, malaria, and typhoid fever. The aqueous extracts have been shown to strongly reduce the release of prostaglandins $\mathrm{I} 2, \mathrm{E} 2$, and $\mathrm{D} 2^{10}$ and have antipyretic properties. ${ }^{11}$ Its antimalarial use has also been documented in the Democratic Republic of Congo. ${ }^{12}$ Further studies elucidated that the methanolic extracts of the plants yielded antiplasmodium flavonolglycosides. ${ }^{13}$ Studies revealed the widespread use of the plant for dengue. ${ }^{14,15,16}$ There are no studies yet to show its effect on haemoglobin but it exerts an inhibitory effect on platelet aggregation ${ }^{10}$ and significantly reduces the plaque-forming capacity of the dengue virus serotypes 1 and $2 .{ }^{16} \mathrm{It}$ is also used to treat sore eyes, cough, diabetes, gastritis, and diarrhea as previously documented in the Cordilleras ${ }^{15,16}$ and in other areas like India, ${ }^{17,18,19,20,21}$ Africa, ${ }^{22,23}$ Fiji, ${ }^{24}$ Cameroon, ${ }^{25}$ Spain, ${ }^{26}$ and Bangladesh. ${ }^{27}$ Its use in diabetes is supported by the improvement in blood glucose levels of albino mice with streptozocininduced diabetes after treatment with its aqueous extracts. ${ }^{28}$ The antispasmodic effect and decrease in gastrointestinal motility ${ }^{29}$ supports its use for digestive disorders.

The parts of the plant that are commonly used are the leaves, roots, and stem. The route of administration is either topical or oral. The methods of preparation include crushing or macerating the leaves, squeezing to obtain the latex, or boiling the leaves, stems, and/or roots depending on the illness it is used for. There are no known contraindications for its use and the only known side effect of this plant is increase in urinary frequency or diuresis. Johnson et al ${ }^{30}$ concluded that it increases urine output in the same way as acetazolamide.

\section{MATERIALS AND METHODS}

This was a cross-sectional descriptive study utilizing the convenience sampling design with the snowball technique to identify key informants in communities known to be users of tawatawa as herbal medicine. Convenience sampling of respondents from the following communities which are known to include residents who are users of $E$. hirta: a coastal and farming Aeta community in Quezon province, a farming community in Pangasinan, a farming community in Agusan del Norte, an urban community in Cebu City, and an urban community in Quezon City. Respondents were selected based on two inclusion criteria of (1) adult member of the selected communities in the Philippines, and (2) knowledgeable about the use of E. hirta in the treatment of illnesses.

An interview guide was used for information collection. No plants were collected. Translation of the interview guide to Filipino was done by a health social scientist and the back-translation was done by a public health practitioner. A photograph of E. hirta was included in the interview guide to ensure the correct identification of the plant. The accuracy and precision of identification of the E. hirta was ensured by showing to the informants vivid pictures of similar looking plants particularly Euphorbia lasiocarpa, Euphorbia polygonifolia, and Euphorbia supine. These plants belong to the same genus and they maybe mistaken for Euphorbia birta. Field researchers were trained on the proper conduct of the interview. 


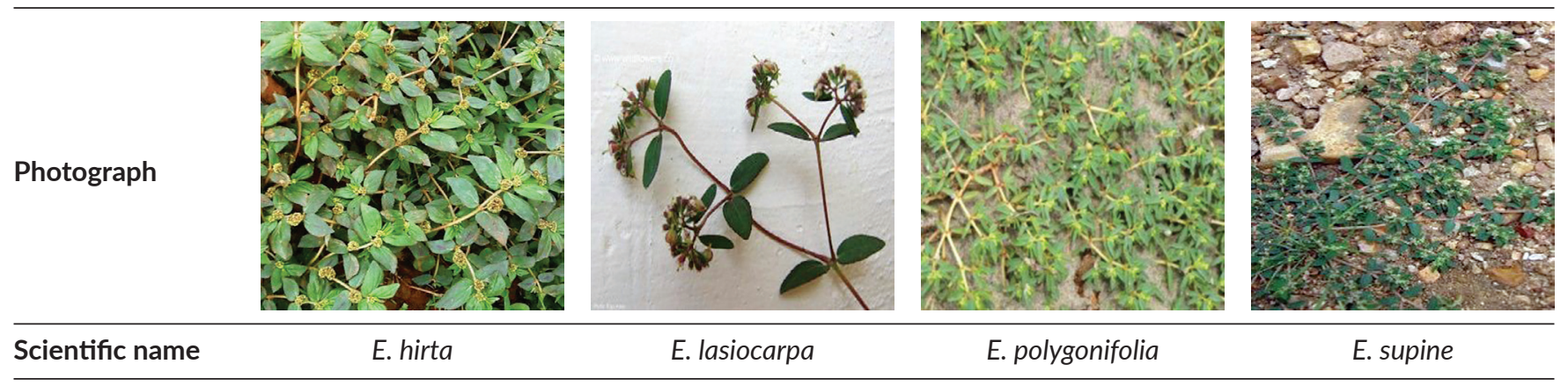

Figure 1. Euphorbiacea species whose photographs were included in the interview tool to test respondent's ability to identify E. hirta correctly.

Protection of privacy and confidentiality of research information including data protection plan was ensured in this study. The informants were protected with anonymity plan. There were no direct benefits of the study to the informants. An informed consent was sought before commencing the interview.

\section{RESULTS}

\section{Demographic Profile of Respondents}

A total of 31 respondents participated. Two were excluded for their inability to distinguish the plant from the other similar looking plants provided photographically.

Majority (93\%) of the respondents were female. The age range was 22- 74 years old. Twenty-seven percent belonged in the 20 to 40 year old categories, $49 \%$ in the 41 to 60 year old categories, and the remaining $24 \%$ were within 61 year old and above category. Of the respondents, $21 \%$ had elementary education, $43 \%$ had high school

Table 1. Respondents Description

\begin{tabular}{lll} 
Demographics & Categories & Number \\
Respondent & Total & $31(100 \%)$ \\
& $\begin{array}{l}\text { Correctly identified E. hirta from } \\
\text { photographs }\end{array}$ & $29(93 \%)$ \\
\hline
\end{tabular}

Table 2. Included respondents descriptions ( $N=29)$

\begin{tabular}{lll} 
Demographics & Categories & Number \\
Sex & Female & $27(93 \%)$ \\
& Male & $2(7 \%)$ \\
\hline Age range & 19 to 30 y.o. & $5(17 \%)$ \\
& 31 to 40 y.o. & $3(10 \%)$ \\
& 41 to 50 y.o. & $8(28 \%)$ \\
& 51 to 60 y.o. & $6(21 \%)$ \\
& 61 y.o. and above & $7(24 \%)$ \\
\hline Highest level of & Elementary school & $6(21 \%)$ \\
educational attainment & High school & $13(43 \%)$ \\
& University & $10(36 \%)$ \\
\hline Residence & Quezon Province & $7(24 \%)$ \\
& Pangasinan Province & $2(7 \%)$ \\
& Agusan del Norte Province & $4(14 \%)$ \\
& Cebu City & $9(31 \%)$ \\
& No answer provided & $7(24 \%)$ \\
\hline
\end{tabular}

education, and $36 \%$ had college education. Twenty-four percent of the respondents were from a coastal and farming Aeta community in Quezon province, 24\% were from a farming community in Pangasinan, $7 \%$ were from a farming community in Agusan del Norte, $14 \%$ were from an urban community in Cebu City, and the remaining $31 \%$ were from an urban community in Quezon City.

\section{Medicinal Uses of Euphorbia hirta}

The 29 included respondents reported 37 instances of medicinal use of E. hirta.

E. hirta is known to the respondents as tawatawa, butobutonesan, malagatas, and mangagaw. Table 3 shows that the first known reported medicinal use of the plant by the study participants was in 1948, and it was used for treating fever.

The earliest reported use of E. birta was in the 1940s (for fever), then in the 1980s (for dengue fever, other fevers, and conjunctivitis), and then in the 2000s (for diabetes and typhoid fever).

It was used specifically for dengue starting only in the 1980s. This is probably because dengue as a disease was not in the public mind until the 1980s.

This study is able to document at least four preparations of E. hirta, as reported by study participants. These preparations are: (1) decoction for dengue, malaria, and typhoid fever; (2) direct application of sap for conjunctivitis; (3) decoction in combination with other herbs (i.e. banaba and balete) for diabetes; and (4) juice extraction of fresh macerated plants for gastritis and diarhhea. The procedures for these preparations are outlined in Table 4.

Table 3. Earliest reported medicinal use of E. hirta in the Philippines by study participants

\begin{tabular}{lcc} 
IIIness & $\begin{array}{c}\text { Number of participants } \\
\text { who reported usage }\end{array}$ & $\begin{array}{c}\text { Earliest } \\
\text { reported use }\end{array}$ \\
\hline Fever & $8(21 \%)$ & 1948 \\
Dengue & $17(46 \%)$ & 1980 \\
Malaria & $6(16 \%)$ & 1980 \\
Conjunctivitis & $4(11 \%)$ & 1980 \\
Diabetes & $1(3 \%)$ & 2012 \\
Typhoid Fever & $1(3 \%)$ & 2003 \\
\hline
\end{tabular}


Table 4. Reported preparations of E. hirta for medicinal purposes, and their side effects

\begin{tabular}{|c|c|c|}
\hline Indication & Preparation & Side effects \\
\hline $\begin{array}{l}\text { Decoction for treating } \\
\text { dengue, malaria, fever, } \\
\text { and typhoid fever }\end{array}$ & $\begin{array}{l}\text { A. Using whole plant: } \\
\text { Remove the roots. } \\
\text { Wash in water. } \\
\text { Boil in } 3-5 \text { cups of water for } 5 \text { minutes. } \\
\text { Let cool before drinking. } \\
\text { Give } 1-2 \text { cups per day for } 2-3 \text { days. } \\
\text { Stop administration once any side effect is noted. } \\
\text { B. Using leaves only: } \\
\text { Take a handful of leaves. } \\
\text { Wash in water. } \\
\text { Boil in } 1 \text { c up of water for } 3 \text { minutes or until the concoction becomes blackish-green. } \\
\text { Let cool before drinking. } \\
\text { C. Using roots only: } \\
\text { Take the roots, wash thoroughly. } \\
\text { Boil in water. } \\
\text { Let cool before drinking. }\end{array}$ & $\begin{array}{l}\text { Frequent urination } \\
\text { Warm urine } \\
\text { Heavy sweating }\end{array}$ \\
\hline $\begin{array}{l}\text { Direct application of } \\
\text { sap for conjunctivitis }\end{array}$ & $\begin{array}{l}\text { Take the stem of the plant and wash thoroughly. } \\
\text { Squeeze the latex directly into the affected eye once a day for } 3 \text { days. }\end{array}$ & None reported \\
\hline $\begin{array}{l}\text { Decoction in combination } \\
\text { with other herbs for diabetes }\end{array}$ & $\begin{array}{l}\text { Boil the whole plant together with banaba and balete leaves. } \\
\text { Let cool. Drink. }\end{array}$ & None reported \\
\hline $\begin{array}{l}\text { Juice extraction of } \\
\text { macerated plants for } \\
\text { gastritis and diarrhea }\end{array}$ & $\begin{array}{l}\text { Take a handful of leaves. } \\
\text { Wash thoroughly and crush/macerate in a clean container. } \\
\text { Extract the juice. } \\
\text { Give to patient } 2 x \text { a week on full stomach. }\end{array}$ & None reported \\
\hline
\end{tabular}

\section{DISCUSSION}

The results of the ethnobotanical survey yielded folkloric uses and reported year of use that are quite consistent with the published literature. Except for cough, gastritis, and diarrhea, the reported folkloric uses of E. hirta have been consistent with published literature. Following the path and rigor as applied to $V$. negundo (lagundi), and B. balsamifera (sambong), it seems that $E$. hirta may be considered a candidate for mainstreaming as a traditional medicine.

\section{Limitations}

The results of this ethnobotanical survey maybe limited by convenient sampling design. Further, while the survey was interviewer guided, the pictures used in the survey tool were not of uniform magnification, which may have led to confusion on the part of the respondents. The study's result maybe used as a baseline for future more comprehensive studies.

\section{CONCLUSION}

Euphorbia birta, locally known as tawatawa, butobutonesan, malagatas, gatasgatasan, and mangagaw, has been used in the Philippines as early as 1948 for treating fever. Since the 1980s, it has also been used for sore eyes, cough, diabetes, dengue, malaria, gastritis, and diarrhea. There are no documented contraindications for use and the only known side effect is increase in urinary frequency. Based on the sampling of this study, therefore, at the current time, according to DOH AO 184 s2004, E. hirta may qualify to be registered with the Food and Drug Administration as a traditionally-used herbal product for fever. However, this study has not found sufficient length of time of traditional use for the treatment of conjunctivitis, cough, diabetes, and dengue, as well as malaria, gastritis, and diarrhea.

\section{Recommendation for future studies}

It is recommended that more comprehensive and large scale studies be conducted, including: (1) identification of folkloric uses of $E$. birta for the treatment of other diseases and (2) determination of different concentrations of extract (crude or semicrude) using the various reported preparations for optimal outcomes for the different reported herbal uses.

\section{Statement of Authorship}

All authors have approved the final version submitted.

\section{Author Disclosure}

All the authors declared no conflicts of interest.

\section{Funding Source}

No external funding.

\section{REFERENCES}

1. Webster GL. Synopsis of the genera and suprageneric taxa of Euphorbiaceae. Annals of the Missouri Botanical Garden. 1994;81:33144.

2. Joshi B.The magical herb "Euphorbia hirta L." An important traditional therapeutic herb for wart disease among the Vangujjars of forest near Kashipur, Uttarakhand. New York Science Journal. 2011; 4(2).

3. Foodrecap.net. Other uses and medicinal benefits of tawatawa./ gatasgatas plant [Online]. 2011 [cited $2011 \mathrm{Feb}$ ].http://foodrecap.net/ health/gatas-gatas-others/.

4. Foodrecap.net. Tawatawa and ginger extract can kill dengue virus [Online]. 2011 [cited 2011 Aug]. http://foodrecap.net/health/camotetawa-dengue-virus/. 
5. Brul T. Tawatawa, anti-dengue and other medicinal benefits. Alagad [Online].2010 [cited 2010 Sep]. http://www.alagad.com.ph/ human-development-and-social-services/100-philippine-medicinalplants/655-tawa-tawa-plant-medicinal- benefits.html.

6. Aragones S. Can 'tawatawa' cure dengue? ABS-CBN News[Online]. 2010 [cited 2010 Sep]. http://www.abs-cbnnews.com/ lifestyle/09/02/10/can-tawa-tawa-cure-dengue.

7. Sisante J. DOH: Don't experiment with 'tawatawa' as dengue cure. GMA News TV [Online]. 2010 [cited 2010 Sep]. http://www. gmanetwork.com/news/story/200931/news/nation/doh-don-texperiment-with-tawa-tawa-as-dengue-cure.

8. Dinglasan RR. Tawatawa not proven dengue cure, but can be taken on the 'side' DOH. GMA News [Online]. 2013 [cited 2013 Feb]. http://www.gmanetwork.com/news/story/296980/lifestyle/ healthandwellness/tawa-tawa-not-proven-dengue- cure-but-can-betaken-on-the-side-doh.

9. Department of Health. Administrative Order No. 184, s. 2004. Guidelines on the Registration of Traditionally-Used Herbal Products. 28 December 2004.

10. Heirmann A, Bucar F. Influence of some traditional plants of Senegal on prostaglandin synthesis. Journal of Ethnopharmacology. 1994;42:111-6.

11. Lanhers MC, Fleurentin J, Dorfman P, Mortier F, Pelt JM. Analgesic, antipyretic, and anti-inflammatory properties of Euphorbia hirta. PlantaMedica. 1991;57(3):225-31.

12. Tona L, Cimanga RK, Mesia K, Musuamba CT, De Bruyne T, Apers $\mathrm{S}$, et al. In vitro antiplasmodial activity of extracts and fractions from seven medicinal plants used in the Democratic Republic of Congo. Journal of Ethnopharmacology.2004;93:27-32.

13. Liu Y, Murakami N, Ji H, Abrev P, Zhang S. Antimalarial flavonol glycosides from Euphorbia hirta. Pharmaceutical Biology.2007;45(4):278-81.

14. Garcia LL, Herrera CL, Capal TV, Melo CL, Dayap LA, Banal RV. Philippine vegetable drugs in common use: their chemical constants. Part II. Philippine Journal of Science. 2003;132 (2):103-8.

15. Balangcod T, Balangcod AKD. Ethnomedical knowledge of plants and healthcare practices among the Kalanguya tribe in Tinoc, Ifugao, Luzon, Philippines.Indian Journal of Traditional Knowledge. 2011;10(2):227-38.

16. Co LL. Common medicinal plants of the Cordillera Region. CHESTCORE (Community Health, Education, Services, and Training in Cordillera Region).Baguio City. Philippines. 1981. 88-90.

16. Tayone WC, Tayone JC, Hashimoto M. Isolation and structure elucidation of potential anti-dengue metabolites from tawatawa (Euphobia hirta Linn.) Walailak Journal of Science and Technology, 2014;11:825-32.
17. Idu M, Obaruyi G, Erhabor J. Ethnobotanical uses of plants among the binis in the treatment of ophthalmic and ENT (ear, nose and throat) ailments. Ethnobotanical Leaflets.2008;13:480-96.

18. Anisuzzaman M, Rahman AHMM, Harun-Or-Rashid M, Naderuzzaman ATM, Islam AKMR. An ethnobotanical study of Madhupur, Tangail. Journal of Applied Sciences Research. 2007; 3(7):519-30.

19. Adsul YD, Mahajan RT, Badgujar SB. Ethnobotanical Euphorbian plants of North Maharashtra Region. IOSR Journal of Pharmacy and Biological Sciences. 2013;7(1):29-35.

20. Balakrishnan V, Prema P, Ravindran KC, Robinson JP. Ethnobotanical studies among villagers from DharapuramTaluk, Tamil Nadu, India. Global Journal of Pharmacology. 2009;3(1):8-14.

21. Ahmad Z, Khan SS, Khan F, Shah F, Wani AA. Studies on the ethnobotanical and ethnomedicinal uses of plants of the Family Euphorbiaceae of Raisen District (MP), India. Science Secure Journals. 2012;1(2):43-6.

22. Dalziel JM. The useful plants of West Tropical Africa. Crown Agents for the Colonies. London.1993:143.

23. Sonibarea MA and Gbileb ZO. Ethnobotanical survey of antiasthmatic plants in southwestern Nigeria. African Journal of Traditional, Complementary, \& Alternative Medicines. 2008;5(4):3405

24. Singh YN. Traditional medicine in Fiji: some herbal folk cures by Fiji Indians. Journal of Ethnophamacology.1986; 15:57-8.

25. Jiofack T, Fokunang C, Guedje N, Kemeuze V, Fongnzossie E, Nkongmeneck BA, et al. Ethnobotanical uses of medicinal plants of two ethnoecological regions of Cameroon. International Journal of Medicine and Medical Sciences. 2010;2(3);60-79.

26. Galvez J, Zarzuela A, Crespo ME, Lorente MD, Ocete ME, Jimenez J. Antidiarrhoeic activity of Euphorbia hirta extracts and isolation of an active flavonoid constituent. PlantaMedica. 1993;58(4):333-6.

27. Rahmatullah M, Mollik MAH, Azam A, Islam MR, Chowdhury MAM, Jahan R, et al. Ethnobotanical survey of the Santal tribe residing in Thakurgaon District, Bangladesh. American Eurasian Journal on Sustainable Agriculture.2009;3:889-98.

28. Kumar S, Rashmiand Kumar D. Evaluation of antidiabetic activity of Euphorbia hirta Linn. In streptozotocin-induced diabetic mice. Indian Journal of Natural Product Resources.2010;1:200-3.

29. Hore SK, Ahuja V, Mehta G, Kumar P, Pandey SK, Ahmad AH. Effect of aqueous Euphorbia hirta leaf extract on gastrointestinal motility. Fitoterapia.2006;77:35-8.

30. Johnson PB, Abdurahman EM, Tiam EA, Abdu-Aguye I, Hussaini IM. Euphorbia hirta leaf extracts increase urine output and electrolytes in rats. Journal of Ethnopharmacology.1999; 65:63-9. 